\title{
Scarheart: Research as Healing
}

\author{
Emily R. O’Hara
}

\section{INTRODUCTION}

As a graduate student writing about intimate partner violence (IPV) programming at an academic institute ${ }^{l}$ I was encouraged to find hard evidence and data that could substantiate my claims. I read the reports, I talked to stakeholders and I analysed statistics. The consensus from the global agenda is that IPV is a pandemic which derives from one partner's desire for power and control over the other partner (UNODC, 2018). The majority of these cases are perpetrated (per my access to current data

${ }^{1}$ The Institute of Development Studies (IDS), University of Sussex, in Brighton, England, United Kingdom.

The words in this chapter were written on Native Land belonging to: Duwamish + Coast Salish people, Ho-de-no-sau-nee-ga (Haudenosaunee), Mohican + Mohawk people, and the Nacotchtank (Anacostan) + Piscataway people.

E. R. O'Hara $(\varangle)$

Washington, DC, USA

W. Harcourt et al. (eds.), Feminist Methodologies,

Gender, Development and Social Change, https://doi.org/10.1007/978-3-030-82654-3_13 
from actual incidences reported) by heterosexual cisgender men against heterosexual cisgender women.

In undertaking my Master's thesis in 2019, I was given the choice of traditional research methodologies such as a case study comparison, a longitudinal study, or data analysis. I found these were limited methodological approaches because of the nuances in IPV. Such traditional research practices come from a scientific approach developed by a predominantly male-dominated gaze where objects are studied as if placed under a microscope in a lab. If things could not be quantified or counted it was dismissed, unworthy of study and seen as not scientific. This is not to say that feminist research is never quantified. But here I want to ask, what does it mean to be a feminist researcher that looks at emotions and feelings as part of the research? How can we value the power of a single story, a sentence, a song? The chapter belongs in a book which is a collection and a celebration of feminist methodologies (Harding, S. 1987) — defined by the authors as a collaborative, collective process. Our chapters explore embodied, personal and situated ways of research (CasasCortés et al., 2008). Because I share an experience with the subject matter that I am researching, this "closeness" made me more aware of where the proposed methodologies for researching the subject fell short.

In this chapter I explore how these feminist ways of doing research can also be forms of healing as we explore "difficult" objects of research. I argue that this approach is a valid one for IPV rather than the predominant "distant" ways of doing research, and show how feminist and collectively personal approaches are able to tell us more, and help us to get closer to what IPV “is about" or "looks like". Let me rephrase:

\section{Method Scientific The}

Experiment first. Ask questions later. When you transcribe and tally, when you collate and count, you flatten any real truth of an experienceturning multi-faceted human existence into two-dimensional representations. Data is representative. Similar to how Harraway writes about genetic expression (Haraway, D.J. 1988; Haraway, D.J. \& Goodeve, T.N. 2000 ), it is important to understand that data is merely representative. It is not the thing(s) it (/them)self(/selves).

And so we must stand up in three-dimensional form and say, "Listen to me. Here is what happened." Without a pen in hand or a camera lens separating the membrane of shared experience. We must sit. With each other. With-and within-ourselves. And listen. Or rather, just "be", 
until we hear that which is the thing itself/are the things themselves: that jellied nothingness that is everything. That spontaneous combustion of random interaction stolen from us during this pandemic. Raw, unadulterated story. There is no survey design. No prefabricated parameters corralling any potential outcomes. No inputs, only out. Except for that internal work which is necessary to arrive fully present in the work of "looking for". Rechercher in French is to search and it seems that the dilemma lies within the word itself: research. Resurface. Resurrection. Perhaps our work now should be less excavation-oriented and more about putting back from whence we took. Perhaps I am not a researcher at all. (Yes, I think that's it.) No more pioneers in their fields. No more colonialist extraction of "pulling stories from the data" or positing of "what the data is trying to tell us". Expeditionary, nay. I am a healer. I don't seek to understand. I understand to seek. My only expectation is that I expect to be surprised. No more "unearthing" of knowledge. Let's put it back. A call for restorative methods. Answer me that.

In this chapter, I will discuss how reflective practice-specifically reflective and reflexive writing-helped me heal from the experience that was also the subject of my dissertation, i.e. preventative IPV programming. I will share snippets of poetry and musings that helped me process my own trauma as well as organize and inform my research. I often threw what I thought was my whole Self into writing or working as a survival mechanism, but I realized that I actually only threw part of myself into the work as a distraction (or as a survival mechanism during abusive relationships). If I truly threw my whole Self into my work, then I would be bringing my emotion and my pain. Instead, I was sublimating. I was screening and editing out a lot of my Self in my papers so as to make it fit the acceptable shape or rubric as demanded by western, colonial academic standards/norms/expectations as reinforced by the institute. A certain number of words per paragraph. A certain number of paragraphs per section. A certain order of sections in each paper. Then, when it came time to write my most significant piece of graduate work, i.e. the one with the most words and pages (quantity; counts; numerical figures), I thought: if, "We... write to become what and who we are" (Hwu, 1998), what about actually throwing your whole Self into your work as a feminist research methodology, Emily? As one of the editors of this book put it, mine is 
an exercise in "centralizing the affective- 'affective mediums'-and the power of the personal". ${ }^{2}$

\section{THeN}

That is what I tried to do in my dissertation by writing as a feminist researcher, a feminist political ecologist: I planted my Self in the work. I attempted to ground my personal experience as the roots of my research in expanding upon Heise's "Ecological Model" (1998: 265). Lori L. Heise first used an ecological framework "to establish what factors emerge as predictive of abuse at each level of the social ecology" (Heise, 1998: 262). She built upon an existing conceptual framework to create a deeper understanding of gender-based violence (GBV). Heise addresses reasons for why men hurt women in her overview of pre-existing "individual explanations for violence [...]" or "social/political explanations" (Heise, 1998: 262). Due to work from theorists like Heise, it is widely understood that GBV does not occur for one specific reason. Rather, multiple factors are responsible. However, multiple factors extend from the focal points of the patriarchy, power and control (UNODC, 2018: 24, 30). It is important to understand the differences in definitions of VAW, GBV and IPV (see Table 13.1). While Heise's "Ecological Model” concept from 1998 uses GBV as a form of violence between a woman and her male partner, when referring to this specific form of violence, the more common term is now IPV. This distinction is necessary as I move ahead and distinguish IPV from other types of VAW programming abroad.

The literature outlines the complexity of the issue and the need for a multi prong approach to address IPV. This same sentiment is echoed by those I spoke with for my qualitative interviews. For instance, as outlined by the World Health Organisation (WHO), there are several overlapping "causes and risk factors found to be associated with intimatepartner violence and sexual violence at the different levels of the ecological model" (Harvey et al., 2007: 9). There is ample evidence about what is missing. However, which type of current environment exists and how can it be leveraged? Which lessons can be learned from other countries where ecological conditions are developed to ensure programmatic success? This

\footnotetext{
${ }^{2}$ Fellow Bolsena retreater and co-editor of this book.
} 
Table 13.1 Definitions of different types of violence based on my review of the current literature (O’Hara, E.R. 2019: 20-21)

\begin{tabular}{|c|c|c|}
\hline Type of violence & Acronym & Definition \\
\hline Gender-based violence & GBV & $\begin{array}{l}\text { The new umbrella term to capture } \\
\text { all forms of violence based on } \\
\text { gender discrimination }\end{array}$ \\
\hline Violence against women and girls & VAW/G & $\begin{array}{l}\text { All forms of violence specifically } \\
\text { targeted at women and girls }\end{array}$ \\
\hline Domestic violence/abuse & $\mathrm{DV} / \mathrm{A}$ & $\begin{array}{l}\text { This is a form of violence/abuse that } \\
\text { is perpetrated by relatives or partners }\end{array}$ \\
\hline Sexual violence & SV & $\begin{array}{l}\text { A form of violence that involves a } \\
\text { sexual act; it can be a form of GBV, } \\
\text { VAW/G and/or DV/A, including } \\
\text { IPV }\end{array}$ \\
\hline Intimate partner violence & IPV & $\begin{array}{l}\text { This is the focal point of my } \\
\text { research. It is a type of violence that } \\
\text { occurs between two intimate } \\
\text { partners. All cases of IPV are a form } \\
\text { of DV/A because IPV is violence } \\
\text { perpetrated by one partner to } \\
\text { another. Similar to DV/A, not all } \\
\text { cases of IPV are SV because violence } \\
\text { can take many forms }\end{array}$ \\
\hline
\end{tabular}

is the gap that I address in my research. This was seen by the examiners at IDS as using mixed language, which they defined as switching between academic and activist language. We were told: pick one thing and be specific, then stick to it and stitch every sentence back to that idea. But I didn't want to do that, so I screeched off in my own direction. After all, "Good critical/feminist theory emerges from placing ourselves in community with visions of social justice" (Carrillo Rowe, 2005: 35). As I progressed in my studies at IDS, taking such courses as Reflective and Creative Practice for Social Change, I realized that the "hard evidence" could not be the only story. And so I wrote from a hard place: from the scars of my heart. Through my writing, I wanted to demonstrate how there is more to the story than what "the numbers" represent. There are a number of faces behind formalised figures. I tried to show my face in my research to illustrate the richness of those innumerable faces that cannot be captured by counting. My thesis was marked down for being "too ambitious" and because my language was both "activist and academic". 
I did not see why I needed to choose between academic or activist language. And to the examiners, who may not engage with the wider feminist collective, my thesis mixed up recounting. But what I wanted to do was write in a new language, so how could they read or understand this new language? This is what I wrote in my notebook during our feminist retreat in Bolsena in August 2019 which led to this edited book. Is feminism a language and if so, how do you speak it? For whom? Who speaks it? I pondered these questions further during my research in the summer of 2019 with stakeholders in the domestic violence (DV) and IPV sectors in the United Kingdom (UK). I had just finished an interview with a subject, a stakeholder. They worked in the UK DV sector and had generously carved out time in their day to speak with me-a researcher, a rover, a rambler-and in this instance, a survivor whose past hurts had come right up to the present. Tears rolled down my face as I hung up the phone. It all seemed so obvious. Prevention is key yet budgetary constraints, political will and priorities cause stagnation in funding preventative measures.

In this hyper digitized data driven time when mega sets of quantifiable results abound and a matrix of information exists, there is clarity in the seeming simplicity of a story. A tale. Raw unadulterated oral exchange. Written words. Story. "There is power in numbers". This is what we are sold. As constructed out of thin air by numerate analysts and repackaged as The Future. Numbers, numbers, numbers. Digital digits. Ones and zeros. Coding, tallying, sequencing. Order. But wherein lies the substance?

There is a proportion often referenced and circulated when discussing gender-based violence (GBV): one in three. " 1 in 3 women and girls experience physical or sexual violence in their lifetime, most frequently by an intimate partner" (UNODC, 2018). "More than one third (34 per cent) of all women and girls ${ }^{3}$ intentionally killed worldwide, or 82 every day, are killed by someone whom they would normally trust and expect to care for them" (UNODC, 2018: 13).

I understand that the number of women hurt and/or killed is a way to communicate the severity of the situation, but is not one life lost to such violence enough to spark action and invest in prevention?

Must everything be counted and quantified?

\footnotetext{
${ }^{3}$ In this instance, "women and girls" are people who identify as women since the data that informed this finding neither separates out nor accounts for those outside of other identifying characteristics.
} 
Is there value in the power of a memory; a sentence; a dance?

\section{Now}

I can only share my story. My experience is an "ethnography of one" as a colleague and friend wisely gave name to my experience (Behar, R. 1999). Her story was actually quite similar to mine. And over time, that is what I continue to find: a decrypted code, a shared rallying cry, a sequenced crucible. A sample so large that it can be neither counted nor compared. How do you measure the insidious injustice that is domestic violence? How does one measure violence that has not yet occurred or may, in fact, never happen?

A reduced number of incidences reported qualifies as success for some organizations that are working to combat IPV. Yet if it is not reported, does this mean that it does not occur? This seems to imply that IPV only occurs if it is reported. Captured. Qualified. Activists, researchers and survivors know this is not the reality. In this chapter, I am inviting you into a story about the use of artistic mediums as research and as a form of healing when writing about the very thing that has caused you so much personal hardship. In my case, it was a battle of deciding where to weave in my own experience with IPV as a survivor's solo "ethnography of one" and when to instead use traditional more "distant" research methodologies in the form of interview accounts from stakeholders who work on IPV.

"We also 'do structure' when we write" (Irwin, 2006: 171). I had lofty goals of hoping that by writing my dissertation, I could humbly attempt to, "decolonize the power relations inherent in the representation of the Other" (Behar \& Gordan, 1995: 4). In other words, by choosing to expose myself in my research, I thought I could somehow bring some more meaning to the numbers.

Meaning, imagination, and hope are as central to the human story as are bones, genes, and ecologies. Neither selfish aggression nor peaceful altruism dominates human behaviour as a whole. We are a species distinguished by our extraordinary capacity for creative cooperation, our ability to imagine possibilities and to make them material, and our powerful aptitudes for belief, hope, and cruelty. (Fuentes, 2017: NP) 
Instead of looking at life through a microscope, I look with my own eyes. In my humble opinion, the study of gender is more scientific than any lab-based simulation.

It is more precise than those projected graphs based on political economy and subsequent theory formulations that did not even account for women or other genders/gender non-conforming people and their experiences.

Irrational economics.

Because gender is the study of life; it is real life-life's specimens of people and "greater" than that, it's the relationship between each other that is the essence of feminist research methodology where $\mathrm{R}=$ Relations and the square root of that is love.: $\mathrm{R}=\sqrt{ }<3 / / \mathrm{R}>$ Self.

While simultaneously realizing that there is no formula for feminism.

Your feminism may not be my feminism.

\section{NEXT}

One funder can see a program as effective while another funder can see the same program as wasteful. Agencies like the UK Department for International Development (DFID) allocate funding and inject programming into regions of the world like Sub-Saharan Africa yet do not take lessons back to its respective biospheres. A colleague of mine from Zimbabwe told me that in their country, when someone rapes someone else, the rapist has to apologize to the entire community, not only the person whom they raped.

I realize that the pandemic of IPV is measured to speak to funders for global health gains (WHO, 2013). I provided some facts and figures about this public health epidemic in my dissertation so that it would hold clout and receive a passable mark. Calculations on the impact of violence by United Nations agencies like the WHO have been one way of communicating the issue. That is what must be done to "make the case" to those in charge of funding. I understand this; I repeat: I get it. I am not here to shame the work or the current approach to the work as necessitated by funders. The catch here, to me, seems to be at what point are "enough" reported incidences of violence, enough to take widespread immediate action through intensive preventative treatment? In the UK context specifically, more money is spent on the acute so-called response piece of the "Life Course Approach", i.e. reactionary spending 
after violence occurs, than on "Anticipation", i.e. preventative spending before violence potentially occurs (UKFPH, 2016: 7) (Table 13.2).

Violence is carried out. Women die. We count the instances and track the patterns. But how many times? 1 in 3 . That's our current ratio. 1 in 3 women experience violence in their lifetimes. I am one of those women. Who is telling their story? Pleading my case. What if she can't make her court date because he has taken the car? There are cracks and crevices in the story of IPV that can never be traced with a traditional magnifying glass or from behind the computer. (She writes from her laptop.) Ask the people in your life if they know someone who has experienced this epidemic which has worsened during the current pandemic of Covid-19. Where is "Operation Warp Speed" for a vaccine to treat those who perpetuate and survive this intimate violence among partners? If only hundreds of thousands would die. Then maybe the funders would take notice, bars would shut down and people's health would be prioritized. But it's a "private matter" of the heart, doomed from the start.

Scarheart. That is what I am. I am more than my exes. I am more than my orgasms. You are more than your organisms. We are more than our microcosm. You are all of the invisible interactions between the people in your community. And you are more than that place where you are. A heart

Table 13.2 Sequential diagram of the "Life Course Approach" (O’Hara, 2019: 18)

\begin{tabular}{|c|c|c|c|}
\hline & Anticipation & Consequence & Response \\
\hline Definition & $\begin{array}{l}\text { "expenditure on } \\
\text { protective and } \\
\text { preventative measures" } \\
(\text { Oliver et al., 2019: 5) }\end{array}$ & $\begin{array}{l}\text { costs incurred by } \\
\text { "individual victims and } \\
\text { the harms they will } \\
\text { suffer during their } \\
\text { period of abuse and the } \\
\text { costs as a } \\
\text { consequence..." (Oliver } \\
\text { et al., 2019: 5) }\end{array}$ & $\begin{array}{l}\text { costs incurred by } \\
\text { "individual victims and } \\
\text { the harms they will } \\
\text { suffer during their } \\
\text { period of abuse and } \\
\text { the costs... in response } \\
\text { to victims" (Oliver } \\
\text { et al., 2019: 5) }\end{array}$ \\
\hline Examples & $\begin{array}{l}\text { primary education, } \\
\text { secondary education, } \\
\text { community-based asset } \\
\text { development (UK } \\
\text { Faculty of Public } \\
\text { Health, 2016) }\end{array}$ & $\begin{array}{l}\text { "property damage, } \\
\text { physical and emotional } \\
\text { harms, lost output, } \\
\text { health and victim } \\
\text { services" (Oliver et al., } \\
\text { 2019: 5) }\end{array}$ & $\begin{array}{l}\text { "police and criminal } \\
\text { justice system" (Oliver } \\
\text { et al., 2019: 5) }\end{array}$ \\
\hline Total cost & $£ 6 \mathrm{~m}$ & $£ 787,718 \mathrm{~m}$ & $£ 488,257 \mathrm{~m}$ \\
\hline
\end{tabular}


with a scar. A story to tell. You are a warrior. A survivor. You have been to hell and back. Now, go forth, and use that: only look back to learn, then bring the good to the present and leave the rest back there so that you can be here now. How? Close your eyes. Take a deep breath. Hold your stomach and your heart. Read this map. This is how you navigate the heart's chambers and the brain's neurons. This is where we start: the future.

I was constantly triaging. Haemorrhaging in silence. No one knew what I had been through-how I had survived; how far I had come; how this year was actually three years in the making. "You shouldn't make funny faces". "I remember when you used to fill out those pants nicely". "If your butt gets any bigger, we're breaking up". "What's up Skeletor?" Ex. 2017 would ask first thing in the morning. "Wow, you are so massive", said Ex. 2019.

It is utterly astounding to me how one man can view your body as too skinny and another as too fat.

For Ex. 2017 and Ex. 2019 and any other ex that I have had: if I just held 2019 while he had a panic attack, if I just gave myself to 2017 after he refused to look at me, if I just tried a little harder, loved a little more, died another bit. Scarheart. That is what I am. It might be who you are. Although, I will never know for certain or be an "expert" for who am I to analyse another's experience? Our research proposals at IDS had to undergo vetting to be deemed ethical yet I feel that it would have been unethical for me to leave my own experience out of the research. Where was that on the University of Sussex's questionnaire?

"It sounds like he didn't want to hurt you. It sounds like he cares about you so much and he told you that he was afraid he might hurt you." These words came out of the British white cisgender heterosexual male police officer's mouth as he sat next to his identical haircut of a counterpart who asked: "Do you think this was coercive control?" I had explained to them both how my partner had told me he thought he might be gay; then said he would kill himself if I left him. So, I stayed. A couple of days later, he pointed to a knife in the kitchen drawer and said, "I keep seeing images of me stabbing you. I'm afraid I'm going to hurt you". His hand was clenched into a fist as though gripping a knife and he motioned it up and down, stabbing the air. "I don't know". I told the officers. "I'd like to think he wasn't trying to manipulate me into staying, but as I speak the events aloud to you, I don't know". The stakeholders with whom I spoke as part of my research after this incident had occurred told me that many 
police officers aren't trained on how to handle these sorts of "domestic" issues. The mental health hotline responder with whom I spoke once my partner had finally fallen asleep after the incident told me that since he was not "standing in front of a train" or "brandishing a weapon"-and due to the fact that the Mental Health Act in England only applies to couples who reside together or are married- "There's nothing we can do." ...there was "nothing" they. could. do.

Speaking events aloud is not enough for me sometimes: I have to write them down. It was not until I had finally managed to safely convince my partner that I was going to come back and just needed some space and escaped a violent situation that I had a moment to reflect. It was not until I was home in my room crying and writing in my journal that I realized I had to call the police. Again, "We write to become who we are" (Hwu, 1998). And I am not just "a survivor". I had endured an abusive relationship with a sociopath from 2015 to 2017 before leaving for the final time and maintaining zero contact only to enter a similar situation with a psychopath. What does that make me? Am I crazy? Wounded? Cursed? No, it makes me a two-time survivor. A hyper-vigilant ultrawarrior. Always on edge for a while and still learning how to trust, how to "be". Now, I will tell you through writing how I heal my Self. A heart with a scar.

\section{Scarheart ${ }^{4}$}

I'm not telling you I know how you feel

because I can't possibly; nor is it my place to know.

I am here to tell you that I have survived. Surely, at one point in time, when I

sat by the water, I thought I could not: I only felt grief and terrible pain.

For I had lost a lover, and a labor of my love. (That's the piece that few talk of,

the feeling of failure and shame for loving someone who hurts you.)

Your experiences are your own. I can listen

to your stories, your truths. I can share 
some of my own or sit with yours

in sacred silence while you share yours.

Either way, please know that you are not alone.

Quite the contrary, you belong to an army now: for you have been to war. And

don't let anyone tell you otherwise. A war without sides aside from the lines

within yourself which outline the need to protect and leave with the desire to

stay and "just be better" to "make it work".

You fought for your life. And you survived.

Similar to soldiers returning home from combat, there will be labels thrown

onto you-some of your own making because you need an identity and some

from others because they need a category, a frame of reference. For they, like

mere civilians, have never entered the land of nuclear destruction that was your

former battle.

But whatever you choose, choose it on your own accord, your own timeline.

This I can tell you: it will take time; a mere year for some or less and many,

many moons for others. In fact, the cartography of your heart and your mind,

your body and your soul, your spirit and your dreams, will be forever altered.

New boundaries; a different topography; caverns unexplored.

But you are safe here. Here in your heart. Drop down a ladder with your broom

and gather your baskets. Wipe down the cobwebs or let them hang; open the

curtains so sunshine floods the ventricles.

Get to know your new home. Cultivate fertile heart space. Take down a book 
from the shelves as you delve inside of this blood-filled, bearing place where

memories become intuition in your arsenal for self-love;

flashbacks disguised as opportunities to rewrite your narrative; thoughts transfer energy into your hands for the capacity to care; connections shift your neurons as the brain undergoes rewiring. Let the Warrior in Training commence, dear scarred hearts.

As my Master's thesis writing came to a close and the submission date drew closer, I realized that I had spoken to people "on the ground" and "experts in the field" yet I also went "into the field" of my heart. I thought the M.A., Gender and Development degree would bring with it the title of becoming a "gender specialist" yet the more I dug deeper, the more I realized that it really meant I was becoming.

I know others in my program are becoming in their own right as well. See how a colleague, my friend Deeksha, says poetry is a form of observation and healing: "I believe that each poem that I write is a way to give words to an emotion that accumulates within me, owing to anything I see, hear, or feel. While some poems or writings are more helpful towards healing me, others are written to acknowledge the pain or the discomfort of an event or thoughts".

The inclusion of their poem in this chapter is to show how alternatives to traditional research using feminist research methodologies, can illuminate issues like IPV or, in the case of the poem, what has been termed "menstrual health management" (MHM) in the development sector. Let the experience of reading the poem soak in. Maybe read it again. Then, read a report issued by a funder or policymaking institution. Are there overlaps? What is missing? Whether IPV or MHM or any development issue, the reliance on a numerate perspective is a form of violence for the development discipline itself. My suggestion is that there is more tactile content in a few staggered stanzas of tacit recounting than can be produced in a publication of dense pages. Through story, a deeper truth appears, and a new belief can be held.

${ }^{4}$ Poem written on 23 February 2020 by Emily R. O'Hara. 


\section{My Stained Skirt}

by Deeksha Sharma (Sharma, D. 2020)

I wore a skirt today morning

Pretty light-grey skirt, flowing merrily

Like breeze flowing on a cloudy day, expecting

Some rain showers today, heavily

I got my period a day before

My period date, but that's normal

And I quickly wore a sanitary pad

Adjusting it neatly and proper

But I was so much in love

With my new skirt- light grey

That I was so determined to wear it

And not wear something dark during the day

I went outside to buy some groceries and then

Walked through the park in my view

The breeze was flowing like my skirt

And, there were some showers too

Showers! from my vagina

Not from the rain

Not its soothing water droplets

But painful red blood, this month again

I could feel the green grass around me dancing

Noticing my uterus bounce and shake

So, I sat on a bench for a while

Feeling my blood vessels break

I pressed my belly and wished I could

Teleport myself back home

Oh! this slimy-thick blood

Moving gently like an earthworm

I stood up and glanced at my skirt behind 
Damn, a red stain on my skirt

Conscious and insecure I felt

Hoping no one sees this, but there's no dearth

No dearth of people staring my skirt

Like something they've never seen

What's the matter if there's a stain?

I'll go home and clean

I kept walking swiftly like a car

That lost its brakes in muddy dirt

And I can notice people

Noticing me, my stained skirt

If I close my eyes to the world

The world can still see me

Oh! I need to rush home

I need to pee

And I reached home

My light grey skirt has a new design

Of two big red polka dots

Imprinted so fine

I washed myself, and

Changed my stained skirt

Walking across the room

I opened my cupboard

Thinking now what I should wear, maybe

Something dark to hide any stain

Smiling at myself, I blinked an eye

I took out a pant, it was white again

The healing, for me, is in the writing of the words and not so much the words themselves. This is similar to how it is the relational process of feminist research that is transformative. More traditional, scientific ways of "knowing" see a certain side of things; they only tell part of the story. Feminist ways of knowing, such as writing, situate us in place; they shift 
us into "being". Reading reports, talking to stakeholders and analysing statistics was re-traumatising as a survivor. My writing brought me back to centre and alleviated my suffering. By digging deeper through reflexive and creative writing, I stitched together the scar tissue and lived the ecological model of myself. As my chapter comes to a close with a final poem of my own, I hope it encourages you to reflect on how you look at policy issues that deal with such intimate experiences and need other ways of seeing. As I share with you how writing has provided healing by helping me come home to myself, I hope I leave you wanting to explore personal, political issues by looking at how they are embodied and felt, not just measured and observed. There is so much more to be said and read, and heard and seen and touched and shared. Let us go forth in a collective healing; towards a more situated, collaborative approach to researching.

\section{A poem for my daughter or son, or they who shall be of gender-none ${ }^{5}$}

And this is how life goes

It hurts and then it doesn't

(Hurts then doesn't)

You're in love and then you're not

(In love then not)

But you always have your self

(Always have self)

Your Self, do you have?

(All ways.)

You always have your strength.

Your self is a home you come back to

To curl up inside

Your self is a home.

To come back to,

yourself.

To nip at your wounds and hide

To let go of life and cry.

To throw down your bags, and lie

Down on the grass, 
all green from your tears.

Of growth and pruning

Your heart took an oath:

I, too will always love you.

You at home; at home in yourself.

Your self is a home to come back to.

And that is how life grows.

\section{REFERENCES}

Behar, R. (1999). Ethnography: Cherishing our second-fiddle genre. Journal of Contemporary Ethnography, 28(5), 472-484. Sage Publications.

Behar, R., \& Gordon, D. A. (1995). Women writing culture. University of California Press.

Casas-Cortés, M. I., Osterweil, M., \& Powell, D. E. (2008). Blurring boundaries: Recognising knowledge-practices in the study of social movements. Anthropological Quarterly, 81(1), 17-58.

Fuentes, A. (2017). Why we believe: Evolution, making meaning, and the development of human natures. University of Edinburgh. Retrieved November 28, 2020, from https://www.ed.ac.uk/arts-humanities-soc-sci/news-events/ lectures/gifford-lectures/gifford-lectures-2017-2018/professor-dr-agustinfuentes-why-we-believe

Haraway, D. J. (1988). Situated knowledges: The science question in feminism and the privilege of partial perspective. Feminist Studies, 14(3), 575-599. (College Park: University of Maryland).

Haraway, D. J., \& Goodeve, T. N. (2000). How like a leaf: A review by T. Scott [Review of 'How like a leaf: Donna J. Haraway-An interview with Thyrza Nichols Goodeve', by Donna J. Haraway and Thyrza Nichols Goodeve] Kairos: A Journal of Rhetoric, Technology, and Pedagogy, 5(1). ISSN 1521-2300.

Harding, S. (1987). Introduction: Is there a feminist method? In S. Harding (Ed.), Feminism and methodology: Social science issues (pp. 1-15). Indiana University Press.

Harvey, A., Garcia-Moreno, C., \& Butchart, A. (2007, May 2-3). Primary prevention of intimate-partner violence and sexual violence: Background paper for $\mathrm{WHO}$ expert meeting. In WHO expert meeting

${ }^{5}$ Poem written on 28 June 2019 by Emily R. O'Hara. 
(pp. 1-38). World Health Organization. Retrieved November 28, 2020, from http://www.ndhealth.gov/injury/nd_prevention_tool_kit/docs/whoprimary-prevention-of-intimate-partner-violence-and-sexual-violence.pdf

Heise, L. L. (1998). Violence against women: An integrated, ecological framework. Violence Against Women, 4(3), 262-290. https://doi.org/10.1177/ 1077801298004003002

Hwu, W.-S. (1998). Curriculum, transcendence, and Zen/Taoism. In Curriculum: Toward new identities, edited by W.F. Pinar.

Irwin, K. (2006). Into the dark heart of ethnography: The lived ethics and inequality of intimate field relationships. Qualitative Sociology, 29(2), $155-175$.

O'Hara, E. R. (2019). Intimate partner violence in the UK: A feminist political ecology perspective. Institute of Development Studies (IDS), 1-61.

Oliver, R. et al. (2019). The economic and social costs of domestic abuse. Research Report 107. London: United Kingdom Home Office. Retrieved April 1, 2019, from https://assets.publishing.service.gov.uk/government/upl oads/system/uploads/attachment_data/file/772180/horr107.pdf

Rowe, A. C. (2005). Be longing: Toward a feminist politics of relation. National Women's Studies Association (NWSA) Journal, 17(2), 15-46.

Sharma, D. (2020). When Words Breathe. Self-Published.

UK Faculty of Public Health (UKFPH). (2016). The role of public health in the prevention of violence (pp. 1-45). UKFPH. Retrieved April 1, 2019, from https://www.fph.org.uk/media/1381/the-role-of-public-health-in-theprevention-of-violence.pdf

United Nations Office on Drugs and Crime (UNODC). (2018). Gender-related killing of women and girls. UNODC. Retrieved April 1, 2019, from https:// www.unodc.org/documents/data-and-analysis/GSH2018/GSH18_Genderrelated_killing_of_women_and_girls.pdf

World Health Organization (WHO), Department of Reproductive Health and Research, London School of Hygiene and Tropical Medicine (LSHTM) and South African Medical Research Council (SAMRC). (2013). Global and regional estimates of violence against women: Prevalence and health effects of intimate partner violence and non-partner sexual violence. WHO. Retrieved April 1, 2019, from https://apps.who.int/iris/bitstream/handle/10665/ 85239/9789241564625_eng.pdf?sequence $=1$ 
Open Access This chapter is distributed under the terms of the Creative Commons Attribution 4.0 International License (http://creativecommons.org/ licenses/by/4.0/), which permits use, duplication, adaptation, distribution and reproduction in any medium or format, as long as you give appropriate credit to the original author(s) and the source, a link is provided to the Creative Commons license and any changes made are indicated.

The images or other third party material in this chapter are included in the work's Creative Commons license, unless indicated otherwise in the credit line; if such material is not included in the work's Creative Commons license and the respective action is not permitted by statutory regulation, users will need to obtain permission from the license holder to duplicate, adapt or reproduce the material.

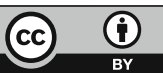

